\title{
The Threat of Aerial Bombing in World War Two Lagos, 1938-1943
}

\author{
Oliver Coates \\ University of Cambridge, Cambridge, u $\mathrm{K}$ \\ orc2o@cam.ac.uk
}

\begin{abstract}
The spectre of air bombing attacks on West African cities during World War Two remains an unexplored dimension of World War Two history. Lagos had long been perceived as vulnerable to attack from neighbouring Dahomey (Benin), and the Fall of France in June 1940 intensified these threats, while increasing anxiety concerning potential Axis raids. Focusing on air-raid planning in Lagos particularly, this article will argue that the possibility of aerial bombing exposed not simply the incapacity of the colonial government and officials' limited understanding of housing and employment in 1940s Lagos, but also the inadequacy of measures to protect African lives. Conversely, the air-raid threat motivated Africans to critique limited government provision and propose their own interpretations of this new and deadly threat. Although the feared aerial raids never materialised, the crisis and anxiety they provoked yield significant insights into wartime Nigeria, local participation in civil defence, and African responses to World War Two more generally.
\end{abstract}

\section{Keywords}

aviation - West Africa - World War Two - Nigeria - home front

'Every day that passes by,' brought Nigerians closer to a 'reality that confronts the people of the British Empire in this war,' opined the West African Pilot. This new horror was epitomised by what the newspaper proclaimed to be the 'danger of Nazi air attack on Lagos.' ${ }^{1}$ Without assuming such a statement to be

1 'Air Raid Precautions,' West African Pilot 12th May 1941. 
representative of African opinion more generally, we may nonetheless observe the visceral fear that putative aerial bombing could engender. Nigerians were confronting a form of attrition at its most 'pure and undisguised' that demolished 'the difference between soldier and civilian,' and engendered debilitating panic on the part of civilian populations. ${ }^{2}$ That the fear of aerial bombing ultimately proved illusory is not of immediate relevance; the social, strategic, and cultural wounds of the bombing scare were inflicted without the deployment of actual explosives. The prospect of air raids revealed the limited capacities of the colonial government to defend Lagos; in doing so, it threw into stark relief the disconnect between African lives in the city and official assumptions concerning urban life and labour. Perhaps most importantly, the spectre of bombing raised provocative questions: if Africans were killed by Axis bombs, did colonial officials view their deaths as equivalent to those of British civilians? What stake could Africans expect to have in defending their city from the bombs? How could colonial subjects, who were expected to volunteer to clear rubble and casualties, while remaining excluded from self-rule, fulfil what the Governor of Nigeria termed their 'obligations as citizens?'?

The air-raid threat occupies an undeservedly obscure position within West African history; the feared raids and the subsequent Air Raid Protection (A.R.P.) plans reveal the limited capacity of the colonial state, both in terms of financial resources and political authority. The war had stretched 'hegemony on a shoestring'4 to its limits, and the township of Lagos, where 'fiscal constraints ensured that the colonial state remained very small' into the early twentieth century, was no exception. ${ }^{5}$ The air-raid threat placed all of this under new and urgent pressure; it did not merely provoke top-down planning, but prompted some Africans to develop their own interpretations and responses to the new menace of aerial attack. Lagos was a key port in the South Atlantic; with a population of 126,474 in 1931, the township included the 1.55 square miles of Lagos Island, as well as the 40,00o residents of the mainland districts of Ebute-Metta and Apapa. In Anglophone West Africa, only Freetown and Takoradi stood competitors to Lagos. ${ }^{6}$ We will examine civil defence measures and their limitations, before showing how Lagosians appraised these efforts and mounted their

2 Sebald 2012, 19; Friedrich 2002, 357; Mellor 2015, 1.

3 'Duty of Citizenship,' Nigerian Daily Times, 14th June 1940.

4 Havinden and Meredith 1996, 235-275; Berry 1993, 24.

5 Mann 2007, 103 .

6 Olukoju 1993, 91; 'Report on Civil Defence Measures in Nigeria (excluding Lagos) for July 1942 as req. in the Sec. of State's secret circular telegram of the 19th of April, 1942,' Civil Defence, Nigeria, Progress Reports, T.N.A., CO 986/72/9. 
own interpretations of the air-raid threat; this article draws on sources from the Nigerian National Archives, Ibadan, and the United Kingdom's National Archives in London, as well as the anti-colonial newspaper the West African Pilot and the pro-government Nigerian Daily Times.

\section{Aerial Bombing and World War Two West Africa}

Aerial attack itself was no novelty in 1940s Africa; from 1912 onwards, it had been used by colonial powers, often against their own African subjects; strategies including machine gun strafing, bombing, and poison gas were used from Morocco to South-West Africa by French, South Africans, British, and the Italians air forces. ${ }^{7}$ Nonetheless, the enemy bombing of civilian cities represented a new threat for World War Two West Africa. ${ }^{8}$ Following the fall of France to the Nazis in June 1940, elaborate civil defence measures were implemented throughout Anglophone Africa; the strategic port of Freetown boasted the earliest infrastructure in the region, beginning with the installation of 4.3 inch guns during the 1930s, and extending, by the early 1940s, to full black-out regulations and dummy raids using real aircraft. ${ }^{9}$ At the outbreak of war, Takoradi had only an old 4 inch gun taken from a sunken merchant vessel, while Lagos had no harbour guns, and relied upon a volunteer machine gun unit. ${ }^{10}$ The fall of France in June 1940 brought Axis aircraft within striking distance of Anglophone African ports; coastal hubs such as Freetown and Lagos were all the more important because hostilities in the Mediterranean necessitated the routing of Allied shipping around Southern Africa. The region's aerial defence thus became of decisive importance; an initial British force of 17 aircraft was based at the Hasting and Waterloo airfields near Freetown, the Jewwang field at Bathurst, and Takoradi, with a West African Air Headquarters established in Freetown.1 ${ }^{11}$ The Americans developed an airbase in the Gold Coast, alongside their existing presence at Georgetown in Liberia. ${ }^{12}$ Aviation logistics formed a second significant area of West African aviation during the war; from 1941, the 'Takoradi Route' was used to ferry aircraft to North-East Africa. ${ }^{13}$ Civil aviation

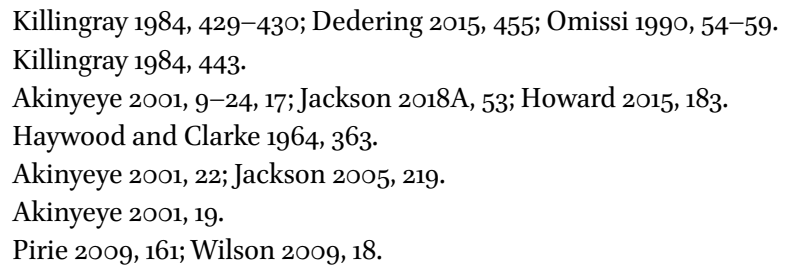


expanded alongside these new routes; Pan-American was contracted to provide services between Bathurst and Khartoum, as well as between West Africa and New York, via Brazil. R.A.F. Ferry Command, the us Army Air Corps, the Free French Air Forces and Trans World Airlines all came to use the 'Takoradi Route;' in Nigeria, key airfields along the route included Lagos, Kano, and Maiduguri. ${ }^{14}$ From 1939, the R.A.F. recruited some 10,0oo West Africans to work in ground duties, but they were not trained as pilots. ${ }^{15}$

What was the nature of the Axis air threat? Nigeria was at risk of attack from French West Africa or l'Afrique-Occidentale française (A.O.F.), despite the fact the Vichy's Armée de l'Air was considerably weakened by the Armistice measures, and had for long 'came a very poor second' to the defence of France itself, the residual groupings based in the region still posed a threat. ${ }^{16}$ The Armée, and its predecessor the Aéronautique had six escadrilles or squadrons in A.O.F., created between 1920 and 1939, at Bamako, Thiès, Gao, and Dakar, although the Gao and Bamako squadrons were dissolved in September 1940, as well as an escadrille in French Equatorial Africa or Afrique Equatoriale Française (A.E.F.), based at Bangui. ${ }^{17}$ By 1932, there were $3^{2}$ French aircraft in A.O.F., 9 in A.E.F., and over 200 in North Africa. ${ }^{18}$ In 1939, it is estimated that the Armée had some 1,078 modern planes, including Potez, Loiré et Olivier, and Loire-Nieuport bombers; in Vichyite A.O.F. some of the Glenn Martin aircraft ordered before June 1940 were available from French North Africa. ${ }^{19}$ German aircraft were also supplied to Governor General Pierre Boisson in return for making the port at Dakar available to South Atlantic U-Boat patrols, the Germans granted the Vichy A.O.F. additional troops and aircraft. ${ }^{20}$ In addition, the Vichyites had some armoured fighting vehicles, and a naval presence at Dakar. ${ }^{21}$ The British anxiety over air attacks had dissipated by late 1942; the following year, the R.A.F. in West Africa became the West African Air Corps (w.A.C.C.), subject not to R.A.F. regulations but to those of the British Army's Royal West African Frontier Force (R.W.A.F.F.). The W.A.A.C., attracted significant African interest because it offered the prospect of an African-manned air force; by late 1944, the Corps boasted some 5,00o members and operated training schools at

\footnotetext{
14 Wilson 2009, 19; Culbert 2002, 576.

15 Jackson $2005,219$.

16 Thomas 1998, 337; Lecoq 2015, 141.

17 Manchon 2013, 16o-174, 710-711, 714.

18 Akinyeye 2001, 15 .

19 Danel 1969, 111; Garraud 2001, 10; Thomas 1997, 662; Haywood and Clarke 1964, 363.

20 Thomas 1997, 661.

21 Haywood and Clarke 1964, 363.
} 
Takoradi and Oshodi, near Lagos. ${ }^{22}$ In 1944, the Air Ministry closed the 'Takoradi' supply route, thereby removing the strategic centrality of airfields across the Gold Coast and Nigeria to the wider Allied war effort.

The historiography of civil defence in Anglophone West Africa remains undeveloped; comparison with research on East Africa and Asia is instructive. In East Africa, Stewart has shown how Nyanza in Kenya responded to the conflict with British settlers by creating civil defence institutions, and, from May 1940, air raid precautions. In Ksumu and Mombasa, practice black out alerts were rehearsed, while in Nairobi A.R.P. preparations extended to trial evacuations of children into the hills close to the city. ${ }^{23}$ Asian cities from Tel Aviv to Hong Kong faced Axis air attacks. ${ }^{24}$ In Ceylon, A.R.P. measures were hastily created and 'authorities in London and Colombo didn't realise until almost too late' that the island risked aerial attack. ${ }^{25}$ The anguish provoked by this new aerial threat went far beyond the fear for immediate survival; in Calcutta, the historian of medieval India Jadunath Sarkar worried that he must 'cling to [his] library to the last moment possible'; while in Madras, zoo animals were shot dead lest they seize upon the opportunity of an air raid to escape captivity. ${ }^{26}$ The consequences of air bombing could also be longer term; in Palestine, Arielli contends, service in wartime civil defence, along with Army experience, provided Jewish fighters with 'valuable military and organisational experience' that would become 'useful during the war of 1948.'27

\section{Planning for an Aerial Attack on Lagos}

Lagos represented Nigeria's key target; it was home to critical port infrastructure, including naval fuelling stations, and the centre of colonial government; by 1903, the value of Lagos trade was £1,000,000. Its importance extended beyond the boundaries of the colony; the port was a key trading hub for West Africa and, after Freetown, the prime British West African port, as well as a major centre in the strategically sensitive South Atlantic. ${ }^{28}$ Lagos, annexed by the British in 1861, had long been considered vulnerable to French invasion; this fear informed the development of the Lagos Battalion in the 186os, and

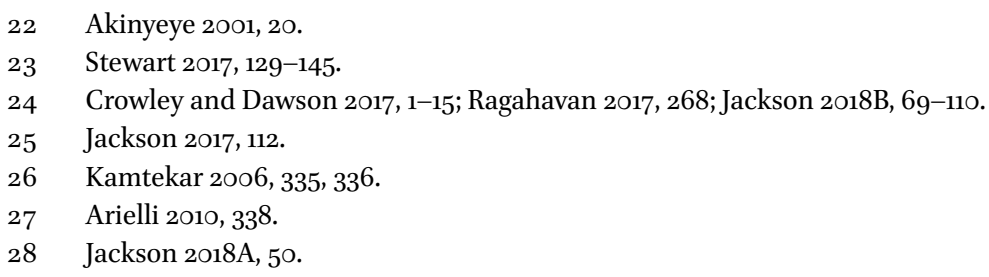


the West African Frontier Force (W.A.F.F.) in 1898/9. ${ }^{29}$ By 1899 , detailed defence plans were drawn-up for Lagos Colony; the lagoons connecting the Dahomeian border, between Badagry and Porto Novo, to Lagos, fifty-two miles away, facilitated a potential attack, as did the prospect of a hostile force landing from the Atlantic. ${ }^{30}$ The geography of Lagos afforded basic protection from marine bombardment; the sand bar off the harbour compelled larger vessels to remain at a substantial distance. ${ }^{31}$ Although a company from Ibadan was available at six hours' notice, the township itself was exposed; in 1904, its police force boasted 400 men, while, in 1899, the Lagos Battalion consisted of 300 Hausas, and 3 European Officers. ${ }^{32}$

These early plans show that Lagos had long been strategically sensitive; direct bombardment did not materialise during World War One, and by the mid-193os some Europeans considered any future war 'unthinkable,' but by the decade's end the colony nonetheless seemed vulnerable. ${ }^{33}$ After the 1935 Italian invasion of Abyssinia, the R.W.A.F.F. was re-organised with a view to mobilising an Expeditionary Force for East Africa. ${ }^{34}$ The colonial government increasingly considered using civilians to protect Lagos; a dedicated 'Lagos Defence Force' was conceived to recruit British workers in the township. ${ }^{35}$ Defence plans accelerated during the later 1930s., but they still assumed that Britain would exercise naval supremacy and that France would remain an ally. ${ }^{36}$ Although ocean attack remained a serious threat, it now contended with aerial bombardment and gas attacks; following the directives of the Imperial Defence Committee, civil servants attempted to calculate what these new threats meant for Lagos. ${ }^{37}$ Unlike marine attack, hostile activities such as assaults with high explosive or

29 Smith 1974, 393; Stapleton 2019, 18.

30 Lagos Defence Scheme, 3, Nigeria: secret despatches from the Secretary of State, Lagos Defence Scheme, T.N.A., F.C.O., 14/ 13566; Acting High Commissioner, Minute, 4 February 1904, Nigeria: secret despatches from the Secretary of State, Southern Nigeria and Lagos in the event of war, Defence Scheme Nigeria, T.N.A., F.C.O. 141/ 13571; Lagos Defence Scheme, Draft, 19th June 1905, Nigeria: secret despatches from the Secretary of State, Lagos Defence Scheme, T.N.A., F.C.O. 141/ 13573, 13.

31 Defence Scheme 1903, Lagos - Notes on Defence scheme by the Inspector-General, West African Frontier Force, T.N.A., C.A.B. $9 / 6$.

32 Lagos Defence Scheme, Draft, 19th June 1905 5, Nigeria: secret despatches from the Secretary of State, Lagos Defence Scheme. T.N.A., F.C.O. 141/ 13573.

33 Haywood and Clarke 1964, 322.

34 Haywood and Clarke 1964, 325.

35 Lagos Defence Force, Minute, F.P.J. Cote, 5 th February 1937, European Reserve Force: Lagos Defence Force, T.N.A., C.O. 583/ 220/19.

36 Haywood and Clarke, 'History,' 325 .

37 11th August 1938, Overseas Defence Committee, Passive Air Defence, Air Raids Precautions Committee for Lagos, N.A.I., COMCOL 1, 2326, Vol. III; Johnson 196o, 244. 
incendiary bombs,' 'gas attacks,' and 'low-flying attack[s] with machine guns' were largely unprecedented factors in British West African defence-planning; the Italian use of mustard gas in 1935 led to R.W.A.F.F. efforts to train African soldiers in the use of respirators. ${ }^{38}$ In addition to the Apapa docks and the wharves on Lagos Island, new targets included in the plans protected strategic infrastructure, including the Iju waterworks, Ijora Power Station, sewerage facilities, pumping facilities, and the Nigerian Railways depot. ${ }^{39}$ The township's naval and industrial installations became strategic priorities for civil defence planners. Although Lagos lacked a single defensive installation in 1939, the port was soon defended by a Coastal Defence Battery, with three watches, each consisting of 3 detachments, 2 Bren guns, and a Forward Observation Point, including a machine gun post was located at the end of West Mole. ${ }^{40}$ Other defence measures included the maintenance of the aforementioned Lagos Defence Force, and a Naval Volunteer Force. ${ }^{41}$ The approaches to Lagos harbour were mined by Axis vessels; the sinking of the dredger Robert Hughes, which exploded on 4th June 1941 at the entrance to the port, killing two men, was attributed either to a magnetic mine or a torpedo. That June witnessed a total of six confirmed hostile explosions at the harbour mouth. ${ }^{42}$

When war came, there was no single civil defence organisation and no staff in Nigeria with experience of A.R.P. or any related field. ${ }^{43} \mathrm{New}$ civil defence legislation was created, carrying significant social consequences, such as the criminalisation of behaviour and travel patterns, as well as the regulation of domestic life; those who contravened A.R.P. regulations were liable to prosecution. It created forms of unpaid labour for Africans in civil defence work, and ambitious, but ultimately limited, interventions into local society. All of

38 Notes on Air Rad Precautions, 25th November 1937, Air Raids Precautions Committee Lagos, N.A.I. COMCOL. 1 2362, Vol. 1; Haywood and Clarke 1964, 323. SDo to COMCOL, 25th March 1939, Draft Regulations for Air Raid Protection, Air Raids Precautions Committee Lagos, N.A.I., COMCOL 12362 , Vol. II.

40 Training - Lagos Coast Defence Battery, 1st July 1941, Lagos Coast Defence Battery, T.N.A., W.O., 173/ 157; Summary of Operational Orders During the month, 1st July 1941, Lagos Coast Defence Battery. T.N.A., W.O., 173/ 157 .

41 Spence 2015, 22.

42 War Diary, June 1941, Lagos Coast Defence Battery, T.N.A., w.O. 173/157; Bourdillon to Secretary of State for the Colonies, 27th June 1941, Loss of the Steam Dredger 'Robert Hughes' in Lagos Harbour and provision of replacement dredger T.N.A., C.O., 583/261/15; Bourdillon to Secretary of State for the Colonies, 27th June 1941, Defence Nigeria, Security of Lagos Harbour, T.N.A., C.O. $968 / 6 / 3$.

43 'Report on Civil Defence Measures in the Township of Lagos for September 1942, drawn up in accordance with the Secretary of State's secret circular telegram of the 18th April 1942,' Civil Defence, Nigeria, Progress Reports, T.N.A., C.O. 986/72/9. 
these measures were built on a raft of civic legislation known as the Defence Regulations; many civil defence measures were incorporated in Part IX 'Passive Defence' of the 1941 iteration. ${ }^{44}$ The Regulations were simply one part of farreaching measures that enabled colonial governors to prevent strikes, censor the press, and incarcerate opponents. ${ }^{45}$

\subsection{Civil Defence in Lagos: Plans and Measures}

Civil defence enabled the Lagos authorities to undertake protective measures, appoint and train personnel, remove damaged buildings, and create first aid posts. ${ }^{46}$ Officials in Nigeria looked to England and to Britain's Asian colonies for guidance on how to prepare for aerial attack. In 1942, civil defence literature was sent to Nigeria from London; while the Colonial Office provided summaries of advice from officials familiar with Japanese raids in South-East Asia. ${ }^{47}$ In September 1942, Africans employed in civil defence included 1876 Air Raid Wardens, 101 Air Raid Ferry workers, 106 Rescue Service workers, 550 in the First Aid Service, and 428 Special Constables; these 3,305 men worked alongside 169 Europeans. ${ }^{48}$ A.R.P. service in Lagos numbered one Chief Warden, 64 Officers (of whom 7 were African), and 1,700 African Wardens and Assistant Wardens. ${ }^{49}$ Members of the civil defence services were issued with a booklet entitled 'Civil Defence,' surveying the practicalities of defending the township, and offering guidance on first aid, fire-fighting, and self-protection. ${ }^{50}$ Public loudspeakers at Ebute Metta and Lagos Island broadcast news relating to civil defence in Hausa and Yoruba. ${ }^{51}$

Civil defence measures encompassed all areas of daily life; the government attempted to locate food reserves to feed half the African population of Lagos

44 The Nigeria General Defence Regulations, 1941 (Government Printer, Lagos, 1944), 82.

$45 \quad$ Brown 2015, 58.

46 'Passive Defence Measures, A-Air Raid, General, and Fire Precaution Measures,' In. The Nigeria General Defence Regulations, 1941 (Government Printer, Lagos, 1944), 82; 'Passive Defence Measures, B-Fire,' In. The Nigeria General Defence Regulations, 1941 (Government Printer, Lagos, 1944), 83 .

47 Minute, Lloyd, 2oth October 1942, Civil Defence, Nigeria, Progress Reports, T.N.A., C.0. $986 / 72 / 9$.

48 Report on Civil Defence Measures in Nigeria in the Township of Lagos for September 1942 as requested in the Sec of State's secret Circular Telegram of the 18th of April, 1942, Civil Defence, Nigeria, Progress Reports, T.N.A., C.o. 986/72/9.

49 Report on Civil Defence Measures in Nigeria (excluding Lagos) for July 1942 as req in the Sec of State's secret circular telegram of the 19th of April, 1942, Civil Defence, Nigeria, Progress Reports, T.N.A., C.O. 986/72/9.

50 Inspector of Produce to Food Supply Volunteers, 1st December 1942, Civil Defence Organsation—Food Supply and Distribution, N.A.I., COMCOL 1, 2729/4.

$5^{1} \quad$ 'Public Loudspeaker for Yaba,' Nigerian Daily Times, 1oth June 1940. 
township, or 8o,ooo people, for one week in case of enemy attack. ${ }^{52}$ Emergency food kitchens were established next to the police barracks at Apapa, Evans Square in Ebute Metta, Town Council Yard in Iddo, Alakoro Fish Market, Idumago Market, and Old Araromi Market in Freeman Street. ${ }^{53}$ The Salvation Army readied its six centres across Lagos to care for those made homeless by bomb damage; stores at St Paul's Breadfruit School and St. Matthias' School, Lewis Street, were used to hold kitchen equipment and first aid materials. ${ }^{54}$ In the event of a serious attack, officials planned to evacuate women and children from Lagos, creating a network of shelters in the villages surrounding the Lagos. ${ }^{55}$ In the event of the destruction of the Carter Bridge, connecting Lagos Island to the mainland, a dedicated Air Raid Ferry Service, consisting of 12 European wardens and 150 Africans, was to be provided by the United Africa Company and Holland West Africa Line to transport personnel, equipment, and casualties across the lagoon. ${ }^{56}$

Lighting restrictions dictated that vehicles driving within a ten-mile radius of the Carter Bridge, a vital piece of infrastructure connecting Lagos Island with the mainland, were only permitted two lamps with dimmed head-lights. ${ }^{57}$ Drivers who failed to comply could face prosecution, a $£_{5}$ o fine and/ or 6 months imprisonment; in domestic houses, removing blinds and shutters on domestic dwellings constituted a separate offence. ${ }^{58}$ Businesses and public places faced routine inspection, and the authorities were to provide accommodation and medical care for individuals left homeless by air attacks. ${ }^{59}$ Buildings deemed to be contaminated by gas could be demolished; the Director of Medical Services was empowered to take over the management of hospitals. ${ }^{60}$

52 Emergency Food Supply Meeting 17th November 1942, Civil Defence Organisation-Food Supply and Distribution, N.A.I., COMCOL 1, 2729/4.

53 Ibid.

54 Ibid.

55 'Report on Civil Defence Measures in the Township of Lagos for September 1942, drawn up in accordance with the Secretary of State's secret circular telegram of the 18th April 1942,' Civil Defence, Nigeria, Progress Reports, T.N.A., C.O. 986/72/9.

56 'Report on the Civil Defence Measures in Lagos Township drawn up in accordance with the Secretary of State's secret circular telegram of the 18th of April 1942,' Civil Defence, Nigeria, Progress Reports, T.N.A., C.O. 986/72/9.

57 'Lighting Restrictions Introduced in Township of Lagos', Nigerian Daily Times, 1st July 1940; A. Olukoju 2004, 217.

$5^{8}$ 'Passive Defence Measures, C—Lighting and Traffic Restrictions,' In. The Nigeria General Defence Regulations, 1941 (Government Printer, Lagos, 1944), 83-85.

59 'Passive Defence Measures, D—Public Safety,' In. The Nigeria General Defence Regulations, 1941 (Government Printer, Lagos, 1944), 85.

6o 'Passive Defence Measures, D-Public Safety,' In. The Nigeria General Defence Regulations, 1941 (Government Printer, Lagos, 1944), 89-9o. 
For A.R.P. purposes, Lagos itself was to be divided into the 'three natural zones' of Lagos Island, Ebute Metta, and Apapa, six further fire unit areas were also created. In order to guard against attack, a network of lookout points was to be created at Magazine Point, Signal Station (East Mole), Bullnose (Apapa), Quartermaster's Store (Ijora), Wireless Reconnaissance Station (Ijoyi), and the Railway Compound (North). ${ }^{61}$ British commercial and mercantile interests dictated this division of space, and thus ensured that African centres of population on the mainland were inadequately protected; while 5 Auxiliary Fire Service (A.F.S.) units were concentrated in the principal areas of European residence on Lagos Island, including the Government Residential Area, only two served the entire mainland. ${ }^{62}$ Key infrastructure was well protected; at Ijora Power Station, the civil defence staff included three assistant mechanical engineers, switchboard operators, power station attendants, and greasers, as well as six firemen, a junior technical staff member, and a mechanical engineer, while at the Iju Waterworks staff included 16 African workers and one British Inspector. ${ }^{63}$

Air raid shelters were key to civil defence; Lagosians were advised that their 'first duty ... [was] to take cover and thus reduce the risk of becoming a casualty.' ${ }^{64}$ Taking 'cover' was not a straightforward move; shelters were only widely built during the latter months of the air raid threat, and then they tended to serve key government and commercial locations. Officials agreed that 'the psychological aspect' of these structures was important, and that they offered 'some sense of protection, even if [it] does not ... amount to very much.'65 Construction was delayed by the absence of building personnel and supervisors. ${ }^{66}$ From 1942, deep shelters were constructed around $20 \mathrm{ft}$. below ground, although it remains unclear how many were finished. Other shelters were constructed from corrugated iron or wooden stick shelters, and packed with loose

61 S.D.o. to COMCOL, 25th March 1939, Draft Regulations for Air Raid Protection, Air Raid Precautions for Lagos, N.A.I., COMCOL 12362 Vol. II; D. Adebayo, A Socioeconomic History of Electrification in Southern Nigeria, 1898-1972, Unpublished PhD Thesis, Cambridge University, 2020, 73 .

62 Whiteman 2012, 47.

63 P.W.D. to COMCOL, 12th October 1938, Air Raid Precautions for Lagos, N.A.I., COMCOL 1, 2362 Vol. III; P.W.D. to COMCOL, 12th October 1938, Air Raid Precautions for Lagos, N.A.I., COMCOL 1, 2362 Vol. III.

64 'Air Raid Precautions,' West African Pilot, 12th May 1941.

65 A.C. Talbot Edwards to Captain D.H. Holley, 4th March 1942, Civil Defence, Nigeria, T.N.A., C.o. $968 / 72 / 8$.

66 'Report on Civil Defence Measures in the Township of Lagos for September 1942, drawn up in accordance with the Secretary of State's secret circular telegram of the 18th April 1942,' Civil Defence, Nigeria, Progress Reports, T.N.A., C.O. 986/ 72/9. 
earth; the slit trenches used in Gold Coast towns were unsuitable due to the marshy soil of Lagos. ${ }^{67}$ Shelters were erected at the Electrical Depot, Public Works Department (P.W.D.) Transport and Water Depot, the Mechanical Stores and Sawmill, the Post \& Telegram Department Post Office, and Elder Dempster Lines offices at Wilmot Point, and, in August 1942, were under construction at Customs Wharf, Apapa, and Secretariat. ${ }^{68}$ They varied in capacity; the Apapa Dockyard installation was the largest with an intended capacity of 1,200; the rest were far smaller, the airport shelter housed 70 individuals, as did the Post Office installation, while the Sawmill structure had a capacity of $130 .{ }^{69} \mathrm{At}$ Alakoro Square, the projected shelter would hold 24 people and protect the Produce Examiner's staff, while at No. 2 Customs Street a similar shelter was to cater for the Agricultural Office. ${ }^{70}$ The strategically important Apapa Dockyard had two further shelters, designed to accommodate around 500 and 250 men respectively. ${ }^{71}$ For many Lagosians, especially those outside of government employment, there was to be no secure form of shelter; 'almost every street in Lagos,' noted on official, 'has an open drain' on one side, and 'the public is ... advised to make use of these drains if no trenches are available. ${ }^{72}$

Fire prevention was critical to A.R.P.; the A.F.S. consisted of units commanded by a European Assistant Fire Officer, and further divided into two separate sub sections; the Fire Officer in Lagos, Captain Holley, had been trained in fire-fighting methods while in England. ${ }^{73}$ The A.F.s. had been organised without any liaison with the regular fire brigade, who were not supposed to attend to fires caused by enemy action unless the A.F.s.'s Chief Fire Officer called them in. ${ }^{74}$ In 1943, the Lagos Fire Brigade (L.F.B.) had a sin-

67 A.C. Talbot Edwards to Captain D.H. Holley, 4th March 1942, Civil Defence, Nigeria, Progress Reports, T.N.A., C.O. $986 / 72 / 9$.

68 Government of Lagos to Secretary of State for the Colonies, 3rd August 1942, Civil Defence, Nigeria, Progress Reports, T.N.A., C.O. 986/72/9.

69 Government of Lagos to Secretary of State for the Colonies, 3rd August 1942, Civil Defence, Nigeria, Progress Reports, T.N.A., C.O. 986/72/9.

70 Government Chemist Lagos to Controller Passive Defence, 14th May 1942, Civil Defence Bomb Protection-Public Shelters, N.A.I., COMCOL 2743/3.

71 Marine Department to Committee for Passive Defence, 15th July 1942, Civil Defence Bomb Protection, N.A.I., COMCOL 2743/3.

72 Governor Nigeria, to Secretary of State for the Colonies, 3rd August 1942, Civil Defence, Nigeria, Progress Reports, T.N.A., C.O. 986/72/9.

73 Draft Telegram, Secretary of State for the Colonies to Governor Nigeria, 23rd July 1942, Civil Defence, Nigeria, Progress Reports, T.N.A., C.O. 986/72/9.

74 Officer Commanding Civil Defence, to Chief Secretary Lagos, 22nd April 1943, Civil Defence Organisation-Auxiliary Fire Service, N.A.I., COMCOL 1 2729/ 1. 
gle European Superintendent, and 70 full-time African staff. ${ }^{75}$ In 1942, the A.F.s. had 11 Officers, and 180 other ranks in 1942 on a part-time basis, along with 11 N.C.o.'s, and 56 firemen; it commanded 1 self-propelled pump, as well as around 25 , ooooft. of unlined canvas hose, and hand-ladders; the L.F.B. possessed two fire tenders with escape ladders, with each unit controlling ten trailer pumps. ${ }^{76}$ Better equipped than the L.F.B., the Auxiliary Service on occasion lent equipment to its peace-time partner, such as a trailer pump supposedly reserved for enemy action; on another occasion the A.F.S. helped the L.F.B. pump out the s.s. Pierre Loti in Lagos harbour. ${ }^{77}$ While the L.F.B. had stations throughout the city at Ikoyi, at Glover Road, Moloney Street, the African Hospital, Ajele Street, Customs (Broad Street), and the Carter Bridge, at Ebute Metta, at the Railway Workshops, and in Ebute Metta itself, at Yaba Market, on Iddo Island, at the PWD Sawmills, and Mechanical Workshops, and in Apapa, at Apapa Wharf, Apapa, and the aerodrome, the A.F.s. were scattered across strategic positions with a towing vehicle for support. ${ }^{78}$ These Auxiliary units were alerted by the Ijora Power Station siren, sounded in alternating bursts to warn all vessels and residents of the city of impending attack; Apapa Dockyard's siren, and the fog horns of Marine Department vessels would later perform the same function. ${ }^{79}$

An array of equipment was needed to provide physical protection from bombs and gas; over 1,300 respirators were required across local government, and plans were made to build a gas chamber for training; 5 decontamination squads were to be based at the Refuse Destructor on Lagos Island, the Health Office at Ebute Metta, and the Seamen's Clinic in Apapa. ${ }^{80}$ The Lagos Town Council, Nigerian Railways, the Posts and Telegram [P\&T] Department, and

75 Officer Commanding Civil Defence, to Chief Secretary Lagos, 22nd April 1943, Civil Defence Organisation-Auxiliary Fire Service, N.A.I., COMCOL 1 2729/ 1.

76 Report on Civil Defence Measures in Nigeria (excluding Lagos) for July 1942 as requested in the Sec. of State's secret circular telegram of the 19th of April, 1942, Civil Defence, Nigeria, Progress Reports, T.N.A., C.O. 986/72/9.

77 Officer Commanding Civil Defence, to Chief Secretary Lagos, 22nd April 1943, Civil Defence Organisation-Auxiliary Fire Service, N.A.I., COMCOL 1 2729/ 1.

78 Fire Brigade $\mathrm{HQ}$ to COMCOL, 5 th October 1938, Air Raid Precautions for Lagos, N.A.I., COMCOL 12362 Vol. III; Officer Commanding Civil Defence, to Chief Secretary Lagos, 22nd April 1943, Civil Defence Organisation-Auxiliary Fire Service, N.A.I., COMCOL 1 2729/ 1.

79 'Lagos Defence Scheme,' Press Notice, 4th September 1939 Test, Acting Commissioner of the Colony to the editors of the Pilot and Times, 31st August 1939, Air Raid Precautions for Lagos, N.A.I., COMCOL 12362 Vol. I.

8o Recommendations of the Air Raid Precautions Committee, Air Raid Precautions Lagos, N.A.I., COMCOL 1, 2362, Vol. I. 
P.W.D. were to benefit from gas training. ${ }^{81}$ During the summer of 1939, air raid planning occupied officials; by August, $£_{7}, 002$ had been spent on air raid protections from the government budget, including 559 ,00o sand bags, while by January 1940, $£ 8$, ooo had been spent on civil defence. ${ }^{82}$ Existing government departments were used to train staff; 3 policemen, 2 officials of the marine and post office, and 1 from the waterworks, electric, health, railway, and fire departments trained civil defence workers. ${ }^{83}$ All of this work was overseen by a dedicated A.R.P. Committee, consisting of representatives from the police, fire brigade, private businesses, and various parts of government, including the Public Works, Medical, Marine, Railway, and Posts and Telecoms Departments. ${ }^{84}$ Based at the Yacht Club on Magazine Point, the Committee's headquarters had a dedicated telephone connection to the local military installations of the Signal Station and the Headquarters of the Machine Gun Platoon. ${ }^{85}$

\section{2}

\section{The Practical and Conceptual Limits of Civil Defence in Wartime} Lagos

A.R.P. measures ran into significant problems that indicated the colonial government's limited power to intervene in local societies. These financial difficulties, combined with the relatively short-lived nature of the aerial threat, and the lack of generalised local sympathy for A.R.P., made Lagos distinct from metropolitan cases, but also from examples in Asia where there was widespread awareness of an imminent threat of Japanese invasion. ${ }^{86}$

A significant problem stemmed from how officials conceptualised A.R.P. in. a colonial African city, and their inability to guarantee adequate protection for Africans. We have seen that soil conditions made trenches impractical and that shelters protected only those working at key European business and government installations. Protective measures for Lagosian civilians were largely absent; 'the provision for trenches and air raid shelters for the civil popula-

81 Recommendations of the Air Raid Precautions Committee, Air Raid Precautions Lagos, N.A.I., COMCOL 1, 2362 Vol. 1.

82 Director of the Marine to COMCOL, 1st August 1939, Air Raid Precautions Lagos, N.A.I., comcol 1, 2362 Vol. v.; Bourdillon to S.S. Col., 3rd January 1940, Civil Defence, Nigeria, T.N.A., C.O. $986 / 72 / 8$.

83 Recommendations of the Air Raid Precautions Committee, Air Raid Precautions Lagos, N.A.I., COMCOL 1, 2362 Vol. I

84 'Lagos Defence Scheme,' Air Raid Precautions Lagos, N.A.I., Comcol 12362 Vol. I.

85 'Lagos Defence Scheme,' Air Raid Precautions Lagos, N.A.I., Comcol 12362 Vol. I.

86 Mukherjee 2015, 145-147. 
tion of Lagos,' warned Nigeria's Governor, was 'not considered feasible..87 This stance continued despite misgivings from the Colonial Office, who expressed 'concern ...' over 'the almost complete lack of shelter protection for the civilian population of Lagos. ${ }^{\prime 8}$ Civilians had to make do with only relatively flimsy surface shelters; made from mangrove wood, bamboo, and earth, even these basic constructions were largely undeveloped by January 1943 due to the shortage of construction staff. ${ }^{89}$ Where built, these shelters could be short-lived; in the Customs and Apapa areas, several of the shelters that had been built in January had collapsed by April. ${ }^{90}$

Tentative and belated steps were made to consider protecting African staff of the P\&T. This necessitated an official examination of the domestic lives of African government employees. These ongoing investigations revealed the limited ways in which government officials could document and operate in African domestic and residential settings. Section 182 of the 1941 Defence Regulations authorised colonial authorities to order every householder to create a list of residents in their homes, and all employers to similarly furnish a list of employees 'and of their wives, children, and dependants.91 In reality, the ability of officials to document and even determine the extent of employment was not readily apparent in the flourishing informal economy of 1940 os Lagos. ${ }^{92}$ During an inspection of the living quarters of P\&T workers in Lagos, Yaba, and Ebute Metta, civil defence officials found that of 118 buildings visited, 84 had no space for any shelter, and 34 had a little space in the back yard. ${ }^{93}$ Among the 84 unsuitable tenement houses, officials determined that in only 22 cases was it possible to build a shelter in the adjoining compound or street. Civil defence was fatally disconnected from social structures within Lagos, where wives often had their own careers, and categories such as 'home' and 'resident'

87 Bourdillon to Secretary of State for the Colonies, 3rd January 1942, Civil Defence, Nigeria, T.N.A. C.O. $968 / 72 / 8$.

88 Bourdillon to Secretary of State for the Colonies, 3rd January 1940, Civil Defence, Nigeria, T.N.A. C.o. 968/72/8; Talbot Edwards to Holley, 4th March 1942, Civil Defence, Nigeria, T.N.A. C.O. $968 / 72 / 8$.

89 Senior Executive Engineer to Marine Department, 16th December 1942, Civil Defence Bomb Protection-Public Shelters, N.A.I., COMCOL 1 2743/3.

90 Marine Department to Chief Passive Defence, 2oth January 1943, Civil Defence Bomb Protection, N.A.I., COMCOL 2743/3; Marine Director to Chief Civil Defence Officer Lagos, 24th April 1943, Civil Defence Bomb Protection, N.A.I., COMCOL 2743/3.

91 'Passive Defence Measures, D-Public Safety,' In. The Nigeria General Defence Regulations, 1941 (Government Printer, Lagos, 1944), 88.

92 McIntosh 2009, 57-58; Lindsay 1999, 783.

93 Education Department to the Civil Defence Officer, 28th October 1942, Civil Defence Bomb Protection, N.A.I., COMCOL 2743/3. 
often obscured changing and complex configurations of kinship, locality, and compound. ${ }^{94}$ The basic elements of A.R.P. in Lagos including basic notions of what constituted 'homes' and 'residents' had been imposed onto Nigerian society.

Maintaining morale in the absence of any apparent attack became a significant problem and grew more acute from early 1942 with the Allied victories in North Africa and Madagascar. ${ }^{95}$ In this changed environment, scares persisted, such as in April 1942 when the battleship Richelieu attempted to break out of Dakar harbour, triggering air attack warnings, and later in October of that year when Vichyites in Dakar grew anxious about a potential Allied attack. ${ }^{96}$ Such threats remained both exceptional and distant from Nigeria; public disinterest only grew. To counter the growing apathy, officials suggested 'competitions, interesting lectures by well-known persons,' 'public review' of civil defence, the observance of Civil Defence Day, and realistic training. ${ }^{97}$ Drawing on experience from Singapore, the Colonial Office recommended 'the provision of uniforms or badges,' which would help 'individuals feel that they have an important part to play;' these measures would have inserted civil defence into a world of official symbol and performance in colonial Nigeria, which at the time focused on events such as the annual Empire Day celebrations. ${ }^{98}$ Severe penalties were recommended for desertion, and improved rates of pay to help deter discontent.

These measures did not translate into local realities; most African civil defence workers were unpaid volunteers who worked other jobs. Save for a small number of European officials, there had never been a peak in public engagement; even at the height of the bombing scare in 1941, 'interest among the rank and file [was] dying and only kept alive at all by the hope of payment.'99 The lack of even nominal payment for the auxiliary firefighters compared negatively to other workers, such as ambulance men who received $8 \mathrm{~d}$ per parade..$^{100}$ Even those who still turned up for parades, perhaps hoping ultimately for financial reward, faced a growing amount of work: 'their altruistic interest in an increasingly uphill task is admirable.'101 Faced with this situation, A.F.s. com-

\footnotetext{
94 Barnes 1986, 75-77.

95 Haywood and Clarke 1964, 373.

$96 \quad$ Haywood and Clarke 1964, 373.

97 Lloyd to Grantham, 4th January 1943, Civil Defence, Nigeria, T.N.A., C.o. 968/72/8.

98 Secretary of State for the Colonies to Officer Administering the Government, Nigeria, 24th March 1942, Civil Defence, Nigeria, T.N.A., Co 968/72/8; Aderinto 2018, 751.

99 Secretary of State for the Colonies to Officer Administering the Government, Nigeria, 24th March 1942, Civil Defence, Nigeria, T.N.A., Co 968/72/8.

100 Ibid.

101 Ibid.
} 
manders begged the colonial government to make a payment of some kind 'to show the men that their work is important.'102 Other officials worried that African goodwill, once exploited, would not be easy to regain after the war, and that:

[if] their help is required at some future date for similar work, it might be found that their enthusiasm will not be forthcoming. ${ }^{103}$

Advice from London assumed both a financial and ideological framework that was sorely lacking in Nigeria; in general, African workers saw little reward, and still less rationale, in civil defence work. The commitment of a minority of African workers remains without a convincing explanation; it is too easy to cite the promise of future payment as a justification, men would surely have realised that money had not so far been forthcoming:

Morale is on the whole good. In a recent alarm practice held in the middle of the forenoon all posts ... were manned with encouraging promptitude even though some of the men had to go as much as three miles on foot from their place of work to their posts. ${ }^{104}$

The problem of morale was real, although it was not total. To some extent explained by the lack of actual bombing raids, and the receding nature of the Axis threat by 1943, the persistence of morale issues throughout 1941 and 1942 suggests that civil defence had failed to capture the imagination of the local population at a more profound level.

We have seen that civil defence was largely conceived at an all-Empire level. While it was admitted that metropolitan and colonial cases might differ, it was readily assumed that one could bring the experience of Hong Kong, Rangoon and Singapore to Lagos; at one point the Nigerian Government unsuccessfully attempted to hire an individual with 'actual experience of air raids on native cities' in Asia. ${ }^{105}$ All of this obscured the question of what stake Nigerians could

\footnotetext{
102 Ibid.

103 Evans to COMCOL, 2nd February 1940, Air Raid Precautions for Lagos, N.A.I., COMCOL 1 2362 , Vol. v.

104 O.A.G. Nigeria To Secretary Of State for The Colonies, 4TH MAY 1942, Civil Defence, Nigeria, T.N.A., C.O. $968 / 72 / 8$.

105 Farmer to Hodsoll, 9th April 1940, Civil Defence, Nigeria: A.R.P. Personnel, Appointments, T.N.A., C.O., 968/74/4; Secretary of State for the Colonies to Officer Administering the Government Nigeria, 24th March 1942, Civil Defence, Nigeria, T.N.A., C.O. 968/72/8.
} 
be expected to have in civil defence projects. Aside from generalities concerning the alleged panic of African crowds, officials rarely concerned themselves with the social and political realities of Lagos. This was apparent in the somewhat florid descriptions of African workers penned by officials in their quest for civil defence staff; A.F.s. firemen, for instance, were to be 'fit and intelligent' men who 'kn[e]w how to obey an order,' but who were also 'not afraid to soil their hands-clerical type not suitable.' ${ }^{106}$ Ex-soldiers, police, and marine deckhands were given as ideal types, along with 'rover scouts,' 'boys brigade,' and labourers. Our point is not merely that these conflations of gender and racial stereotypes revealed the utter gulf between British civil defence officials and their unpaid African workforce, but that they demonstrated a tendency to misread local society in terms of casual generality.

If civil defence was stymied by its unwillingness to take the local context in Nigeria with any seriousness; it was also restricted by the financial shortages that characterised many colonial labour and social projects. ${ }^{107}$ By January 1940, only $£ 8$, ooo had been spent on civil defence, and it was estimated that existing measures would require an additional $£_{3,5}$ oo per annum to maintain; given that Bourdillon estimated air raid protection alone would cost $£_{30} \mathrm{O}, \mathrm{OOO}$ in total, spending by 1940 was a small proportion of the investment required. ${ }^{108}$ By late 1942, when A.R.P. measures were being reduced by the colonial authorities, an official warned that 'if we do not get equipment we shall have difficulty in keeping our organisations ... on more than a care and maintenance basis. ${ }^{109}$ Although A.R.P. drills were conducted early in the war, it was simply too expensive to run large-scale black-out trials in Lagos with any frequency; occasional drills continued during 1941, and the projected bill of $£$ 10o per actual black-out was already deemed precariously costly. ${ }^{110}$ At the anti-gas school, it was too expensive to build a fence around the perimeter for $£ 145$; the building had to rely on a newly sunk well; it was not possible to pay the $£ 425$ to connect it to the water supply. ${ }^{111}$ The quality of existing industrial buildings across the township was often poor; the shops at Apapa dockyard were found to be 'so old that

106 Director Marine to Comcol 1st August 1939, Air Raids Precautions Committee for Lagos, N.A.I., COMCOL 1, 2362 Vol. v.

107 Spear 2003, 9 .

108 Bourdillon to S.S. Col., 3rd January 1940, Civil Defence, Nigeria, T.N.A., C.o. 986/72/8.

109 Grantham to Lloyd, 17 th December 1942, Civil Defence, Nigeria, T.N.A., C.O. 986/72/8.

110 COMCOL to C.S.G., 12th September 1939, Air Raid Precautions for Lagos, N.A.I., COMCOL 1, 2362 Vol. v; C.s.G. to com COL, 13th September 1939, Air Raid Precautions for Lagos, N.A.I., COMCOL 12362 , Vol. v.

111 Report of a meeting of the Anti-Gas Sub Committee, 3rd October 1938, Air Raid Precautions for Lagos, N.A.I., COMCOL 12362 , Vol. III. 
it [was] impossible to make them gas proof'; they were likely to crumble under the pressure of high-explosive shells. ${ }^{112}$

\subsection{Between Fear and Critique: The Air Raid Threat and the Nigerian Press}

African responses to colonial air warfare have been unduly neglected. Perhaps because of the few documents' elucidating African responses to air bombing, historians have, as Omissi observes, 'given scant notice to the victims of [Africa-based] bombers. ${ }^{\prime 13}$ The African press provides ample insight into local responses to many aspects of the global conflict; newspaper editors had partisan agendas, the West African Pilot was fiercely critical of the colonial government, while the Nigerian Daily Times tended to support official perspectives. ${ }^{114}$ Not all Nigerians regarded civil defence with apathy; both anti- and pro-government sections of the Lagos press provided sustained commentary and critique on the question. Air attacks figured sporadically in the Nigerian press until 1943; they reflected a more general interest in aviation and its possibilities for Africans during the war. ${ }^{115}$ Newswire services and West African newspapers brought details of Europe's air wars to literate Nigerians. ${ }^{116}$ This was part of a wider body of journalism focusing on Nazi ideology and atrocities, and exploring Hitler's personality. ${ }^{117}$ These tales of aerial warfare prompted African interest in forming a Nigerian Air Squadron that could 'glide ... into the clouds ... to wherever the enemy might be found.'118

The air raid threat had the potential to temporarily redefine the boundaries between metropolitan society and the elite of colonial Nigeria. As far afield as London, officials observed that 'accounts of air raids,' must:

have percolated to a considerable section of the African population, and judging by the interest shown in A.R.P. matters by the local African press I

112 Director of the Marine to Comcol, 3rd October 1938, Air Raid Precautions for Lagos, N.A.I., COMCOL 12362 , Vol. III.

113 Omissi 1990, 107.

114 Omu 1978, 64-69.

115 James 2018, 596.

116 'R.A.F. Fight Germans,' West African Pilot, 19th September 1939; 'German Air Force Will Bomb Open Towns,' West African Pilot, 14th September 1939; 'Fleet Air Arm Uses African Ju'ju To Stop Theft of Socks,' West African Pilot, 24th May 1941; 'British Fighter Command Aeroplanes Attack Occupied France in Lightning Dive Actions,' West African Pilot, 6th June 1941.

117 'Nazism and Fate of Africans,' West African Pilot, 4th November 1939; 'Concentration Camp,' West African Pilot, 2nd November 1939; Clarke 1986, 4 o.

118 'A Nigerian Air Training School,' West African Pilot, 24th July 1941. 
think it can be assumed that the more sophisticated element of the population are more 'A.R.P. minded' than in many other parts of the Empire. ${ }^{119}$

It was not simply a question of being 'A.R.P. minded;' African journalists reacted in ways that stressed Nigeria's centrality to global events, and aligned Nigerians with the civilians of war-torn Europe. 'Every day that passes by,' lamented one article

Brings to the people of Nigeria particularly of the island of Lagos, the reality that confronts the people of the British Empire in this war ... it is at the same time a warning of what may happen to us if the Huns come this way, and also an eye opener about the terrible onslaught that the Nazis are inflicting upon the defenceless women and children of Europe. This realisation alone should make us ready to do our little bit to minimise the danger of Nazi air attack on Lagos ... if the terrible ordeal of air attack comes to us as it is now being experienced by innocent men, women, and children in Europe. ${ }^{120}$

The article claimed that the indiscriminate and total nature of air attack created a direct parallel between African and European victims. It is possible that such a view marked a strategic attempt to adopt Allied propaganda to further the Pilot's own interests; conversely we should not underestimate African antifascist sentiment. ${ }^{121}$ Government propaganda encouraged Africans to identify with the war effort, but the Pilot also promoted these views independently of official statements; "[we] must be prepared to face what other people in Europe and Africa have been facing for some time now,' asserted one editorial comment, while another observed how 'the youths of Britain, France, and their empires are shedding their precious blood. ${ }^{122}$ These statements of Nigerian investment in the Allied war effort were not uncommon; H.O. Davies, Secretary General of the Nigerian Youth Movement, argued that Nigeria should assure imperial Britain of the 'greatest of all sacrifices' of its youth to defend 'a common heritage,' while the Pilot had editorialised on the 'loyalty of all Nigeria at

119 Secretary of State for the Colonies to o.A.G. Nigeria, Gold Coast, Sierra Leone, Gambia, 24th March 1942, Air Raid Precautions in West Africa, Civil Defence, Nigeria, T.N.A., c.o. $968 / 72 / 8$.

120 'Air Raid Precautions,' West African Pilot, 12th May 1941.

121 Clarke 1986, 38-42.

122 'Hitlerism Totters,' West African Pilot, gth September 1939; 'Let Us 'Buck Up,' West African Pilot, 12 th June 1941. 
this approaching hour of supreme sacrifice.'123 One African journalist averred that we 'must remember the far more difficult lot of those in the towns of Great Britain,' who had experienced 'complete black-out ... long before actual night raids started'; such African sympathy for British civilians should not be minimised to strategic self-interest. ${ }^{124}$ As Mordi argues, some Africans 'keenly followed the slide to war,' and were 'acutely aware of the dire consequences' of Axis supremacy; many were angered by Italy's invasion of Ethiopia in 1935, and mindful of Nazi racial ideology. ${ }^{125}$ They raised significant sums to help British civilians and the Allied war effort; in 1942, African philanthropic fund-raising had raised $£_{1,400}$ towards a Spitfire in Nsukka, and $£ 10,290$ from Kano. ${ }^{126}$

The threat of air raids caused longer-standing insecurity to surface in new ways. Crime represented a major concern, as commonly feared in blacked-out European cities as much as in African ones; in Lagos, reporters worried that the black-out provided 'encouragement to thieves and bad characters.'127 This problem, took on a specifically Lagosian dimension when newspaper editorials connected it to a more general panic concerning the delinquent behaviour of urban youths known as 'Boma Boys.' ${ }^{128}$ In fact, crimes that took advantage of A.R.P. measures were not a preserve of the township; during the June 1941 blackouts in Abeokuta, 4 robbery cases were reported in one week, as well as two raids on shops. ${ }^{129}$ In Lagos, the Superintendent of Police advised homeowners and businesses to padlock their properties during the hours of darkness. ${ }^{130}$ Newspaper editorials urged 'extra vigilance' on the part of the police to counteract the threat of theft and violence. ${ }^{131}$ These fears were justified; responding to a temporary increase in black-out measures in the summer of 1941, the Pilot remarked that:

dwelling houses, shops, etcetera are being broken into by those who think that they have got the finest opportunity to profit by the misfortune of the people ... every day brings in its own tale of woe ... if something is not done

\footnotetext{
123 Mordi 2019, 843.

124 'A.R.P. Measures,' Nigerian Daily Times, 1st August 1940; 'The Black-Out,' Nigerian Daily Times, 21st September 1940.

125 Mordi 2019, 853; Asante 1974, 292-293.

126 Clarke 1986, 21.

127 'Control of Lighting,' Nigerian Daily Times, 9th July 1940; Adey, Cox, and Godfrey 2016, 3.

128 George 2011, 837; Aderinto 2015, 275-278; Fourchard 2006, 115-137; Fourchard 2005, 300302.

129 'Black-Out at Abeokuta,' Nigerian Daily Times, 26th June 1941.

130 'How to be Prepared Against Air Raid Emergency', Nigerian Daily Times, 14th June 1941.

131 'New Lighting Restrictions,' Nigerian Daily Times, 2nd July 1940.
} 
now, the visitations into the houses and shops will develop into robbery with violence on the highways, or ... something even worse than that. ${ }^{132}$

Predicting an escalation from robbery to violent crime would lead to 'chaos and fear,' the editorial demanded increased police patrols, or the appointment of special constables. But even the appointment of extra patrols was not a straightforward solution; one observer worried that a volunteer corps of Special Constables might simply perpetuate the crime spree; such 'volunteers [had to be ] ... persons whose integrity and reliability are absolutely unquestionable.'133 If the black-out brought fears of 'brigands' and thieves to the fore, these worries also reflected a more generalised inability of the colonial government to impose order and control over the city, regardless of whether a black-out was in operation or not.

Africans also critiqued the government for its failure to impose sufficiently extensive civil defence protections. Appearing shortly after a broadcast speech by the Commissioner of the Colony on Lagos radio, one editorial took aim squarely at the lack of protection for Africans, arguing that 'we must ... be fully prepare[d] for anything at any moment,' the writer continued to lament how 'it is unfortunate that it has not been possible to provide air raid shelters' for Nigeria. ${ }^{134}$ Observing that a recent practice had failed, enticing large crowds into the streets, the article continued by warning that such gatherings would form 'an inciting target:'

for the enemy's bombs and machine guns and expose even the hospital to grave risk ... We should have thought that in case of a raid, people already under cover would be allowed to remain quietly where they were until the 'All Clear' ... sounded. ${ }^{135}$

Stressing the proximity of Spanish and French territory, another editorial demanded:

we want to know what plans for evacuation are being prepared for the people, not only for non-Africans but also for Africans ... ${ }^{136}$

\footnotetext{
132 'Black-Out Lawlessness,' West African Pilot, 23rd June 1941.

133 'Matters of Moment,' Nigerian Daily Times, 4th July 1940.

134 'Our Air Raid Defence,' West African Pilot, n1th June 1941.

135 'Our Air Raid Defence,' West African Pilot, 11th June 1941.

136 'Let Us Buck Up,' West African Pilot, 12th June 1941.
} 
The critique was not merely general, but contained an element of pressure, suggesting that officials had failed to act decisively since the war began:

the fate of the people must not be left to chance as was done in the past ... We must also make plans for shelters, in case of aerial bombing, plans like these should now engage the attention of our Authorities and we expect the Governor to tell us what is being done about them in his next public announcement on the radio ... the people must be calm, but the Government must be energetically active. ${ }^{137}$

Communications and planning shortcomings attracted pointed criticism; existing A.R.P. leaflets, such as the 1940 publication 'Protecting Lagos From Fire,' were only available in English. Such measures were deemed to have little effect in 'a community where illiteracy [is] preponderate', and, the article recommended, A.R.P. measures should instead be 'broadcast in the vernacular.'138

The new post of Air Raid Warden, a product of the A.R.P., measures, attracted mixed responses. One editorial was thankful that wardens:

... are now protected by our laws and those who think that they can molest them without compunction are finding that they can only do so to their sorrow. ${ }^{139}$

These lines hint at a local hostility to such wardens that must remain in the realm of conjecture due to the absence of supporting evidence. In any case, protection was deemed 'very essential' because 'the public':

Owes gratitude to these Wardens for giving of their time and service to prepare themselves to work for the protection of their fellow men and women.

Despite this positive role, another 'side of the question' existed, particularly in 'the attitude of some of the wardens themselves.' Citing the comments of an anonymous warden, the editorial continued to reveal the suspicion that:

137 'Let Us Buck Up,' West African Pilot, 12th June 1941.

138 'A.R.P. Measures,' Nigerian Daily Times, 1st August 1940.

139 'Our Air Raid Wardens,' West African Pilot, 14th June 1941. 
When one comes in contact with [some wardens] ... on patrol and notice[s] their method of approach to the public, one is challenged to ask whether they are mannerful, polite, and cautious or whether they are competent to teach and educate the general public ... ${ }^{140}$

It is impossible to ascertain the substance behind this complaint, but we can observe the existence of a notion of what constituted 'proper' behaviour on the part of an A.R.P. warden, and how this was closely linked in the comments of this particular Warden with the mission of 'teach[ing]' and 'educat[ing]' the public. Ambassador of the entire edifice of A.R.P. measures, the mission of the warden himself was, at least in this case, being styled into a persona displaying sufficient education, 'knowledge', and 'seriousness of mind' to indicate a bid to socially mandated respectability. ${ }^{141}$

African commentators also pointed disparities within civil defence, such as the government's reluctance to run trial air raids, and the racial discrimination that kept Africans from senior roles in civil defence. The necessity of trial air-raids was underscored by one Lagosian, Philip Awonka, who wrote to the Daily Times offering suggestions on how to run A.R.P. practices. 'Some practical demonstration' of a night-time raid was vital, Awonka contended, so as to give the wardens an opportunity to practice, and ensuring that 'the masses ... have a full understanding of what an Air Raid means.' ${ }^{\prime 42}$ These steps would bring Nigeria into line with, what Awonka termed, 'more advanced countries,' where 'the people were taught what to do in case of an air raid.'143 Racial discrimination in hiring civil defence staff was also noted by African observers; the implication here was that some Africans were keenly interested in helping with civil defence, but were barred from doing so due to racism. 'I know personally,' argued one writer in the pro-British Daily Times that 'many Africans feel very strongly' about the refusal to hire local people to defend Lagos, and suggested that:

it is inevitable that there should be the suspicion that colour or racial discrimination has something to do with it ${ }^{144}$

\footnotetext{
140 Ibid.

141 Iliffe 2004, 246.

142 'The Black Out—A Suggestion,' Nigerian Daily Times, 18th September 1940.

143 'The Black Out-A Suggestion,' Nigerian Daily Times, 18th September 1940.

144 'Matters of Moment,' Nigerian Daily Times, 4th July 1940.
} 
Similar discrimination meant that Africans were excluded from the European Reserve Force, formed in 1933 to provide potential officers and N.C.o.s to the R.W.A.F.F.; the R.A.F. had been criticised for the limited opportunities it provided for West Africans in the Force. ${ }^{145}$ As we have seem, officials had prejudicial views of the Africans they expected to hire to civil defence roles, often drawing on gendered stereotypes that discriminated against clerks. Concerns over racism were sufficiently grave to necessitate the Governor of Nigeria's intervention, stressing that, in the military, 'Africans and Europeans [were] drilling in the ranks side by side' and that 'there [was] no question whatever of racial distinction.' ${ }^{146}$

\section{Conclusion: After the Bombing Threat}

By the winter of 1942/3, the bombing threat had receded; on 8th November 1942, around 90,ooo Allied troops invaded French North Africa as part of Operation Torch, triggering the removal of Axis powers from the region. ${ }^{147}$ A February 1943 meeting of the West African War Council decided that land-based air attack 'could be disregarded,' and the remaining civil defence organisations were to be disbanded, outside of the ports of Lagos and Victoria. ${ }^{148}$ 'So long as the military position in Africa does not deteriorate,' wrote one Lagos official, 'we are safe from air attack, since Germany and Italy have no aircraft carriers;' the threat from 'incendiary bombs ... does not at present exist,' and bombardment from a submarine remained the sole risk. ${ }^{149}$ Anti-aircraft defences were moved away from West Africa, and any civil defence experts in the region were to be relocated; in Lagos, officials realised that their work was now on 'a care and maintenance basis. ${ }^{\prime 150}$ Certain restrictions continued, such as those regarding seaward-facing lights; in March 1943, some 2,ooo Europeans and Africans con-

145 Haywood and Clarke 1964, 322; 'Nigerians and the RAF,' West African Pilot, 18th September 1941; 'A Nigerian Air Training School,' West African Pilot, 24th July 1941.

146 'H.E.'s Second Weekly Broadcast,' Nigerian Daily Times, 26th July 1940.

147 Bouche 1979, 41; Walker 1987, 667.

148 Governor Lagos to Secretary of State for the Colonies, 6th February 1942, Civil Defence Nigeria, Progress Reports, T.N.A., C.O. 986/72/9.

149 Minute by N.C.s., Civil Defence Service Lagos, November 1942, Civil Defence Organisation-General, N.A.I., COMCOL 1 2729; COMCOL to Chief Secretary, August 1943, Civil Defence Organisation-Rescue Service, N.A.I., COMCOL $12729 / 2$.

150 Achimota to Secretary of State for the Colonies, 17th March 1943, Civil Defence Nigeria, Progress Reports, T.N.A., C.O. 986/72/9; Tiny to Wing Commander T. Hodsoll, undated, Civil Defence, Nigeria, T.N.A., C.o. $968 / 72 / 8$. 
tinued to be employed in civil defence, many leaving their work places to take part in two hour unpaid shifts. ${ }^{151}$ Some restrictions continued, aimed at countering submarine attack; vehicles were still prohibited from driving southwards along Victoria Beach Road and the Marina, and ships anchored in the pool were only allowed to show lights with the Resident Naval Officer's permission ${ }^{152}$ By October 1943, civil defence services were being disbanded and equipment soldoff; departing staff were allowed to keep their uniforms. ${ }^{153}$

Civil defence represents a significant aspect of civilian experience on the African 'home front,' particularly in major urban centres. Although unrealised, the air raid threat demonstrates the extent to which the global war impressed itself upon the lives of urban Nigerians, and also highlights the scale and shortcomings of colonial government plans to implement civil defence measures, including A.R.P. in colonial cities. ${ }^{154}$ There was insufficient funding to buy enough materials to build, maintain, or extend shelters; it was too costly to run routine air-raid practices, and there was neither the administrative knowledge nor the official will-power to create shelters in most African residential areas. As if these crippling financial setbacks were not enough, there were serious problems regarding the manner in which civil defence was understood and explained in colonial Lagos. Material was not printed in local languages, and broadcasts remained sporadic, with some areas of Lagos, such as Yaba, lacking direct access to a public speaker for part of the war. In any case, government officials and certain business representatives lacked faith in the ability of Africans to respond to any threat; old spectres of mass panic, and untrustworthiness soon surfaced, and the whole edifice of 'A.R.P.' came to rely on the nebulous notion of an African 'of good social standing.' Despite these paternalistic assumptions, thousands of Africans voluntarily left their day jobs to engage in the hazardous work of defending Lagos.

If, as Korieh contends, 'the military history of [World War Two] has often overlooked the enormous burden placed upon the African population,' then the air-raid threat represents a localised, but far-reaching example of this bur-

\footnotetext{
151 C.S. Lagos to Provincial Secretary and Commissioner of Colony, 27th November 1942, Civil Defence Organisation-General, N.A.I., COMCOL 1, 2729; COMCOL to H.C.S., 5th March 1943, Civil Defence Organisation-General, N.A.I., COMCOL 1, 2729.

$15^{2}$ Comcol to C.S.G., 21st May 1943, Civil Defence Organisation-General, N.A.I., COMCOL 1, 2729 .

153 СОмсоL to Financial Secretary Lagos, 22nd October 1943, Civil Defence OrganisationFood Supply and Distribution, N.A.I., COMCOL $12729 / 4$.

154 'Our Air Raid Defence,' West African Pilot, 11th June 1941.
} 
den. ${ }^{155}$ African journalists were active in pointing to shortcomings in the colonial government's civil defence measures; they highlighted the persistence of racial inequality in recruitment for air-raid wardens and the distribution of shelters, official insouciance over mock air-raids. Less directly, these observers suggested that the colonial government was unable to adequately police Lagos during the black-out, and noted that the very staff hired to protect local civilians might play a role in those criminal enterprises undertaken in the darkness. The threat of air-bombing had a limited but potent ability to insert Nigeria into the global war effort.

\section{Bibliography}

\section{Primary Sources}

The National Archives, London (T.N.A.)

C.A.в., 9/6/21, Lagos - Notes on Defence scheme by the Inspector-General, West African Frontier Force Scheme 1903 .

c.o., 583/ 220/19, European Reserve Force: Lagos Defence Force.

C.o., $583 / 261 / 15$, Loss of the Steam Dredger 'Robert Hughes' in Lagos Harbour and provision of replacement dredger.

c.o. 968/6/3, Defence Nigeria, Security of Lagos Harbour.

c.o., 968/72/8, Civil Defence in Colonies, Nigeria.

c.o., 986/72/9, Civil Defence, Nigeria, Progress Reports.

C.O., 968/74/4, Civil Defence, Nigeria, A.R.P. Personnel.

F.C.O., 141/13566, Nigeria: secret despatches from the Secretary of State, Lagos Defence Scheme.

F.C.O., 141/ 13571, Nigeria: secret despatches from the Secretary of State, Southern Nigeria and Lagos in the event of war, Defence Scheme Nigeria, 1908.

F.C.O., 141/13573, Nigeria: secret despatches from the Secretary of State, Lagos Defence Scheme.

W.O., 173/157, Lagos Coast Defence Battery.

Nigerian National Archives, Ibadan (N.A.I.)

COMcol 1, 2729, Civil Defence Organisation-General.

COMCOL 1 2729/1, Civil Defence Organisation-Auxiliary Fire Service.

COMcol 1 2729/2, Civil Defence Organisation-Rescue Service.

COMCOL 1 2729/4, Civil Defence Organisation-Food Supply and Distribution.

155 Korieh 2020, 240. 
COMCOL 2362, Vol. 1, Air Raids Precautions Committee Lagos.

COMCOL 1, 2362, Vol. II, Air Raid Precautions for Lagos.

COMCOL 1, 2362, Vol. III, Air Raid Precautions for Lagos.

COMCOL 1, 2362, Vol. v, Air Raid Precautions for Lagos.

comcol 2743/3 Civil Defence, Bomb Protection-Public Shelters.

\section{Newspapers}

'Hitlerism Totters,' West African Pilot, gth September 1939.

'German Air Force Will Bomb Open Towns,' West African Pilot, 14th September 1939.

'R.A.F. Fight Germans,' West African Pilot, 19th September 1939.

'Concentration Camp,' West African Pilot, 2nd November 1939.

'Nazism and Fate of Africans,' West African Pilot, 4th November 1939.

'Public Loudspeaker for Yaba,' Nigerian Daily Times, 1oth June 1940.

'Duty of Citizenship,' Nigerian Daily Times, 14th June 1940.

'Lighting Restrictions Introduced in Township of Lagos,' Nigerian Daily Times, 1st July 1940.

'New Lighting Restrictions,' Nigerian Daily Times, 2nd July 1940.

'Matters of Moment,' Nigerian Daily Times, 4th July 1940.

'H.E.'s Second Weekly Broadcast,' Nigerian Daily Times, 26th July 1940.

'A.R.P. Measures,' Nigerian Daily Times, 1st August 1940.

'The Black-Out—A Suggestion,' Nigerian Daily Times, 18th September 1940.

'The Black-Out,' Nigerian Daily Times, 21st September 1940.

'Air Raid Precautions,' West African Pilot 12th May 1941.

'Fleet Air Arm Uses African Ju'ju To Stop Theft of Socks,' West African Pilot, 24th May 1941.

'British Fighter Command Aeroplanes Attack Occupied France in Lightning Dive Actions,' West African Pilot, 6th June 1941.

'Our Air Raid Defence,' West African Pilot, 11th June 1941.

'Let Us ‘Buck Up,' West African Pilot, 12th June 1941.

'How to be Prepared Against Air Raid Emergency,' Nigerian Daily Times, 14th June 1941.

'Black-Out Lawlessness,' West African Pilot, 23rd June 1941.

'Black-Out at Abeokuta,' Nigerian Daily Times, 26th June 1941.

'A Nigerian Air Training School,' West African Pilot, 24th July 1941.

'Nigerians and the RAF,' West African Pilot, 18th September 1941.

Unpublished PhD Theses

D. Adebayo, A Socioeconomic History of Electrification in Southern Nigeria, 1898-1972, Unpublished PhD Thesis, Cambridge University, 2020. 


\section{Secondary Works}

Aderinto, S. 2015. "O! Sir I do not know either to kill myself or to stay": Childhood Emotion, Poverty, and Literary Culture in Nigeria, 1900-1960. Journal of the History of Childhood and Youth, 8.2, 273-294.

Aderinto, S. 2018. 'Empire Day in Africa: Patriotic Colonial Childhood, Imperial Spectacle and Nationalism in Nigeria, 1905-6o,' Journal of Imperial and Commonwealth History, 46.4, 731-757.

Adey, P., D. Cox, and B. Godfrey, 2016. Crime, Regulation and Control During the Blitz: Protecting the Population of Bombed Cities. London: Bloomsbury Academic.

Akinyeye, Y. 2001. 'The Air Factor in West Africa's Colonial Defence, 1920-1945: A Neglected Theme,' Itinerario, 25.1, 9-24.

Arielli, N. 2010. 'Haifa is still Burning: Italian, German, and French Air Raids on Palestine during the Second World War,' Middle Eastern Studies, 46.3, 331-347.

Asante, S.K.B. 1974. 'The Italo-Ethiopian Conflict: A Case Study in British West African Response to Crisis Diplomacy in the 1930s,' Journal of African History, 15.2, 291302.

Barnes, S. 1986, Patrons and Power: Creating a Political Community in Metropolitan Lagos, Manchester: Manchester University Press.

Berry, S. 1993. No Condition is Permanent: The Social Dynamics of Agrarian Change in Sub-Saharan Africa, Madison: University of Wisconsin Press.

Bouche, D. 1979. 'Le Retour de l'Afrique Occidentale Française dans la lutte contre l'ennemi aux côtés des alliés,' Revue d'histoire de la Deuxième Guerre mondiale, 29.114, 41-68.

Boyne, W. (ed.) 2002. Air Warfare: An International Encyclopedia, Santa Barbara: ABC Clio.

Brown, C. 2015. 'African Labor in the Making of World War II,' In J. Byfield, C. Brown, T. Parsons, et al. (eds), Africa and World War Two. Cambridge, Cambridge University Press, 43-67.

Byfield, J., C. Brown, T. Parsons, et al. (eds.), 2015. Africa and World War Two, Cambridge: Cambridge University Press.

Clarke, P.B. 1986. West Africans at War, 1914-1918, 1939-1944, London: Ethnographica.

Crowley, M. and S. Dawson (eds) 2017. Home Fronts: Britain and the Empire at War, 193945, Woodbridge: Boydell \& Brewer.

Crowley, M. and S. Dawson 2017 B, 'Introduction: Home Fronts and the Empire at War,' In M. Crowley and S. Dawson (eds) Home Fronts:Britain and the Empire at War, 193945, Woodbridge: Boydell \& Brewer, $1-15$.

Culbert, T. 2002, 'South Atlantic/ Trans-Africa Air Route,' In. W. Boyne (ed), Air Warfare: An International Encyclopedia, Santa Barbara: ABC Clio.

Danel, R. 1969. 'L' Armée de l' Air Française à l' entrée en guerre,' Revue d'histoire de la Deuxième Guerre mondiale, 19.73, 111-116. 
Dedering, T 2015. 'Air Power in South Africa, 1914-1939,' Journal of Southern African Studies, $41.3,451-465$.

Fourchard, L. 2005. 'Urban Poverty, Urban Crime, and Crime Control: The Lagos and Ibadan Cases, 1929-45,' In. S. Salm and T. Falola, African Urban Spaces in Historical Perspective, Rochester: University of Rochester Press, 291-319.

Fourchard, L. 2006. 'Lagos and the Invention of Juvenile Delinquency in Nigeria,' Journal of African History, 46, 115-137.

Friedrich, J. 2002. The Fire: The Bombing of Germany, 1940-1945, New York: Columbia University Press.

Garraud, P. 2001. 'L' action de l' armée de l' air en 1939-1940: Facteurs structurels et conjoncturels d'une defaite,' Guerres mondiales et conflits contemporains, 202/3, 7-31.

George, A. 2011. 'Within Salvation: Girl Hawkers and the Colonial State in Development Era Lagos,' Journal of Social History 44.1, 837-859.

Havinden, M. and D. Meredith, 1996. Colonialism and Development: Britain and Its Tropical Colonies, 1850-1960, London; Routledge.

Haywood, A. and F. Clarke. 1964. The history of the Royal West African Frontier Force, Aldershot: Gale \& Polden.

Howard, A, 2015. 'Freetown and World War II: Strategic Militarization, Accommodation, and Resistance,' In. J. Byfield, C. Brown, T. Parsons, et al. (eds), Africa and World War Two. Cambridge, Cambridge University Press 183-199.

Iliffe, J. 2004. Honour in African History, Cambridge: Cambridge University Press.

Jackson, A. 2005. The British Empire and the Second World War. London: Hambledon Continuum.

Jackson, A. 2017. 'Ceylon's Home Front during the Second World War,' In. In M. Crowley and S. Dawson (eds) In Home Fronts: Britain and the Empire at War, 1939-45, Woodbridge: Boydell \& Brewer, 111-129.

Jackson, A. 2018A. Of Islands, Ports and Sea Lanes: Africa and the Indian Ocean in the Second World War, Warwick: Helion.

Jackson, A. 2018B. Ceylon at War, 1939-1945, Warwick: Helion, 2018.

James, L. 2018. 'The Flying Newspapermen and the Time-Space of Late Colonial Nigeria,' Comparative Studies in Society and History. 6o.3, 569-598.

Kamtekar, I. 2006. 'The Shiver of 1942,' In K. Roy (ed), War and Society in Colonial India. Delhi, Oxford University Press, 330-357.

Killingray, D. 1984. 'A Swift Agent of Government: Air Power in British Colonial Africa, 1916-1939,' Journal of African History 25, 429-444.

Korieh, C. 2020. Nigeria and World War II: Colonialism, Empire, and Global Conflict. Cambridge; Cambridge University Press.

Lecoq, T. 2015. 'Refaire L' Armée Française (1943-1945): L' outil militaire, l' instrument politique, le contrôle opérationnel,' Guerres mondiales et conflits contemporains. 257, 137-153. 
Lindsay, L. 1999. 'Domesticity and Difference: Male Breadwinners, Working Women, and Colonial Citizenship in the 1945 Nigerian General Strike,' American Historical Review, 104.3, 783-812.

Manchon, J. 2013. L'aéronautique militaire française outre-mer, 1911-1939. Paris: Presses de l'université Paris-Sorbonne.

Mann, K. 2007. Slavery and the Birth of an African City: Lagos, 1769-1900, Bloomington: Indiana University Press.

Mellor, L. 2015. Reading the Ruins, Cambridge: Cambridge University Press.

McIntosh, M. 20o9. Yoruba Women, Work, and Social Change, Bloomington: Indiana University Press.

Moore, A. 2018. Bombing the City: Civilian Accounts of the Air War in Britain and Japan, 1939-1945, Cambridge: Cambridge University Press.

Mordi, E. 2019. 'What if the Huns Come? Imperial Britain's Attitude Towards Nigerians' Enthusiasm for Military Service During the Second World War, 1939-1942.' Asian and African Studies, 54.6, 838-857.

Mukherjee, J. 2015. Hungry Bengal: War, Famine and the End of Empire, Oxford: Oxford University Press.

The Nigeria General Defence Regulations, 1941, Government Printer, Lagos, 1944.

Olukoju, A. 1993. 'Population Pressure, Housing and Sanitation in West Africa's Premier Port-City: Lagos, 1900-1939,' The Great Circle, 15.2, 91-106.

Olukoju, A. 2004. 'Urban Transport in Metropolitan Lagos,' In. T. Falola and S. Salm (eds.) Nigerian Cities, Trenton: Africa World Press, 211-236.

Omissi, D. 1990. Air power and colonial control: the Royal Air Force 1919-1939, Manchester: Manchester University Press.

Omu, F. 1978. Press and Politics in Nigeria, 1880-1937, London: Longman.

Pirie, G. 2009. Air Empire: British Imperial Civil Aviation, 1919-39, Manchester: Manchester University Press.

Ragahavan, S. 2017. India's War: The Making of Modern South Asia 1939-1945 London, Penguin.

Roy, K. (ed) 2006. War and Society in Colonial India. Delhi, Oxford University Press.

Salm, S. and T. Falola, (eds.) 2004. Nigerian Cities, Trenton: Africa World Press.

Salm, S. and T. Falola (eds.) 2005. African Urban Spaces in Historical Perspective, Rochester: University of Rochester Press.

Sebald, W.G. 2012. 'On the Natural History of Destruction,' London: Notting Hill Editions.

Smith, R. 1974. 'The Lagos Consulate, 1851-1861: An Outline,' Journal of African History, $15 \cdot 3,393-416$.

Spear, T. 2003., 'Neo-Traditionalism and the Limits of Invention in British Colonial Africa,' Journal of African History, 44, 3-27.

Spence, D. 2015. Colonial naval culture and British imperialism, 1922-67, Manchester: Manchester University Press. 
Stapleton, T. 2019. 'Martial Identities in Colonial Nigeria,' Journal of African Military History, 3, 1-32.

Stewart, A. 2017. 'Nyanza at War: Kenya and the Mobilization of Britain's Colonial Empire,' In. M. Crowley and S. Dawson (eds), Home Fronts: Britain and the Empire at War, 1939-45, Woodbridge: Boydell \& Brewer, 129-145.

Thomas, M. 1997. 'After Mers-el-Kébir: The Armed Neutrality of the Vichy French Navy, 1940-43, English Historical Review, 112: 447,643-670.

Thomas, M. 1998. 'At the Heart of Things? French Imperial Defence Planning in the Late 1930s,' French Historical Studies, 21. 2, 325-361.

Walker, D. 1987. 'oss and Operation Torch,' Journal of Contemporary History, 22 (4), 667670.

Whiteman, K. 2012. Lagos: A Cultural and Historical Companion, Oxford: Signal Books.

Wilson, J. 2009. Report on the Progress of Civil Aviation, 1939-1945, Dronfield: West African Study Circle. 